\title{
Effect of Galium verum aqueous extract on growth, motility and gene expression in drug-sensitive and -resistant laryngeal carcinoma cell lines
}

\author{
MARIANNE SCHMIDT ${ }^{1}$, CLAUS-JUERGEN SCHOLZ ${ }^{2}$, GEORGIANA-LUMINITA GAVRIL ${ }^{3}$, \\ CLEMENS OTTO $^{1}$, CHRISTINE POLEDNIK ${ }^{1}$, JEANETTE ROLLER ${ }^{1}$ and RUDOLF HAGEN ${ }^{1}$ \\ ${ }^{1}$ Department of Otorhinolaryngology, University of Wuerzburg, 97080 Wuerzburg; ${ }^{2}$ Interdisciplinary Center \\ for Clinical Research - Microarray Core Unit, University of Wuerzburg, 97078 Wuerzburg, Germany; \\ ${ }^{3}$ NIRDBS/‘Stejarul’ Biological Research Centre, 610004 Piatra Neamţ, Neamţ, Romania
}

Received October 1, 2013; Accepted November 13, 2013

DOI: $10.3892 / \mathrm{ijo} .2013 .2220$

\begin{abstract}
Galium verum, also known as Lady's Bedstraw, is a herbaceous perennial plant of the family Rubiaceae, native to Europe and Asia and used in traditional medicine as an anticancer medicine. It is used as a decoction in most traditional recipes, applied externally as well as internally. We produced a Galium verum decoction and applied it in vitro to chemosensitive (Hep-2 and HLaC79) and chemoresistant, P-glycoprotein-overexpressing (Hep2-Tax, HLaC79-Tax) laryngeal carcinoma cell lines. It could be demonstrated that Galium aqueous extract is cytotoxic for all cell lines. A detailed spheroid-based 3D invasion analysis of Hep2 and Hep2-Tax in semisolid collagen gels and on different extracellular matrix coatings was performed, which showed an inhibition of invasion by sublethal concentrations of Galium decoction and proved to be even more pronounced in the more aggressively invading chemoresistant Hep2-Tax cell line. Gelatinolytic activity of MMP-2 was downregulated in three of the four cell lines. Angiogenesis (endothelial tube formation) in contrast, was not affected by Galium aqueous extract. Gene expression array on HLaC79 and Hep2 cell lines treated with Galium decoction vs. untreated controls revealed no unique pathway activation patterns in these cells. Results are discussed with respect to the use of herbal drugs as a preventive and/or a concomitant therapeutic approach in head and neck cancer.
\end{abstract}

Correspondence to: Dr Marianne Schmidt, Department of Otorhinolaryngology, University of Wuerzburg, Josef-SchneiderStrasse 11, D-97080 Wuerzburg, Germany

E-mail: schmidt_m2@klinik.uni-wuerzburg.de

Key words: Galium verum, cancer, carcinoma, head and neck, paclitaxel, herbal drug, metastasis, in vitro, head and neck squamous carcinoma cell

\section{Introduction}

According to an analysis in 2009 of over 3,000 cases of primary head and neck tumours in Germany 2009, the outcome has not improved significantly from 1995 to 2006, despite changed treatment strategies. Especially the 5-year overall survival rate for carcinomas of hypopharyngeal origin is very low with $27.2 \%$ (1). Moreover, in advanced laryngeal and hypopharyngeal cancer the functional and cosmetic deformations produced by surgery can be very disabling for the patients. Chemotherapeutic treatment is meanwhile commonly used for advanced head and neck cancer in order to preserve laryngeal and/or pharyngeal structures. Paclitaxel is one of the agents used and generally seems to be powerful, however, it failed to reach a local-regional tumour control in $12 \%$ of patients according to a previously published study (2).

Galium verum, also known as Lady's Bedstraw or Yellow Bedstraw, is an herbaceous perennial plant of the family Rubiaceae, native to Europe and Asia. The dried plants were used to stuff mattresses, and the flowers were also used to coagulate milk for cheese production in the past. Studies on Galium verum predominantly originate from the Asian continent, where traditional medicine is more frequently embedded in culture and everyday life. In central European countries or the USA traditional herbal cure has been replaced by modern, science-based therapy. However, traditional phyto-medicine gains more and more attention, especially with respect to alternative treatment of cancer. When mainstream medicine reaches a limit of success, patients search for alternatives.

The cut and dried aerial parts of the plant, 'Herba gallii lutei', are used for homeopathic purposes. These are still used for exogenous treatment of psoriasis or delayed wound healing or as a tea with diuretic effect for the cure of pyelitis or cystitis (3). Today the use of Galium verum is considered to be obsolete, although it is still referred to in popular nonscientific publications and internet platforms as an anticancer medicine. One example for such literature is the compendium of Treben (4), which is neither science based nor accepted in medicine, but very popular and well sold in German speaking countries of Europe. 
Even in non-scientific literature the role of Galium verum in treatment of cancer is controversially discussed. While Willfort (5) recommends Galium tea for treatment of tongue cancer by mouth rinsing and drinking, Neuthaler (6) disclaims this to be sheer mischief. Treben (4) describes a few cases of tongue and larynx carcinoma patients with remission of tumour and/or sickness caused by Galium tea. However, she damped enthusiasm herself by stating, that God's assistance is also necessary for healing of severe diseases.

On scientific level, a variety of bioactive substances have been identified in Galium verum plants such as Iridoinglycosides (7-9), flavanoids $(8,10,11)$, anthraquinones (12) and chlorogenic acid (13). Galium species are known to have antioxidant [Galium verum (14)], antimicrobial/antifungal [Galium tricornutum (15)], antifeedant [Galium aparine (16)] and insecticidal [Galium melantherum (17)] properties.

According to Jonathan Hartwells' survey (18) Galium verum was traditionally used in Europe and Northern America for treatment of cancerous ulcers or breast cancer. Amirghofran et al (19) showed a cytotoxic effect of Galium mite methanolic extracts on K561 and Jurkat cells. Zhao et al isolated Diosmetin from Galium verum plants and showed protective effects on the thymus of U14-bearing mice (20).

According to popular scientific advice (4) and a number of recommendations circulating in diverse internet platforms, we have tested the influence of a Galium verum 'tea' (decoction) on growth and behaviour of head and neck cancer cell lines, either paclitaxel-sensitive or resistant.

\section{Materials and methods}

Cell lines and cell culture. The head and neck squamous carcinoma cell line HLaC79 was established from a lymph node metastase of a laryngeal squamous cell carcinoma (21). The cell line was grown with RPMI-1640 medium (Seromed, Munich, Germany), supplemented with $10 \%$ fetal calf serum (FCS). HLaC79 cells were treated with $10 \mathrm{nM}$ paclitaxel. A resistant clone was isolated by selective trypsination of single clones. The permanent HLaC79 clonal cell line HLaC79-Tax was cultured in RPMI-1640 medium, supplemented with $10 \%$ FCS and $10 \mathrm{nM}$ paclitaxel. Hep2 cells were grown in MEM medium, supplemented with $10 \%$ FCS. A paclitaxelresistant clone was isolated according to the procedure in HLaC79-Tax.

Human umbilical vein endothelial cells (HUVEC) were isolated as described elsewhere (22). They were grown in ECGM (Provitro, Berlin, Germany) medium.

Galium verum decoction. Dried and cut Galium verum L. leaves (Herba gallii lutei) were kindly provided by Dr Ivo Pischel, PhytoLab GmbH \& Co. KG. (Vestenbergsgreuth, Germany). Tea was prepared as follows: $100 \mathrm{ml}$ boiling water were poured over $15 \mathrm{~g}$ of dried and powdered Galium leaves. After cooling down, the supernatant was cleared by centrifugation and sterile filtration. Aliquots were frozen at $-80^{\circ} \mathrm{C}$. One batch of frozen Galium extract was used for all experiments.

TLC analysis/sample identification. Samples were analyzed using thin layer chromatography, a physical method to separate complex chemical substance mixtures on a stationary phase with a mixture of solvents. The method relies on dynamic differential migration of substances in the mixture as a result of adsorption characteristics, molecular weight, and solubility (23). As samples for TLC Galium decoction, a methanolic Galium verum extract (24) and standards were used. They were applied to Silica gel 60 F264 plates (Merckmillipore.com). As solvents ethyl acetate - formic acid - acetic acid - water (100:11:11:27) for flavones or toluene - ethyl acetate - formic acid (50:40:10) for polyphenolcarboxylic acids were used. Compounds were determined and documented by exposure to UV light at $365 \mathrm{~nm}$ with a Camag TLC documentation system (Camag.com). The following standards were used: apigenol, luteolin, apigenol-7-O-glucoside, luteolin7-O-glucoside, quercetol and rutoside for flavones; chlorogenic acid, caffeic acid, rosmarinic acid, ferulic acid, and p-coumaric acid for polyphenolcarboxylic acids.

Cell viability and proliferation assay. Cells were seeded at 5000 cells/well in 96-well plates. They were treated with increasing concentrations of Galium verum aqueous extract (50 and $100 \mu \mathrm{l} / \mathrm{ml}$ ) for $48 \mathrm{~h}$. Controls were kept in medium supplemented with $100 \mu \mathrm{l} / \mathrm{ml}$ water. Cell proliferation was measured after $48 \mathrm{~h}$ by replacing the culture medium with medium containing $1 \mathrm{mg} / \mathrm{ml}$ MTT. After $4 \mathrm{~h}$ of incubation, MTT-staining solution was replaced by isopropanol and cells were incubated at $37^{\circ} \mathrm{C}$ for $45 \mathrm{~min}$. The colour conversion of MTT to a blue formazan dye was measured with an ELISA reader at a wavelength of $570 \mathrm{~nm}$. The amount of formazan dye is in direct proportion to the number of metabolically active cells in the culture. Relative toxicity was calculated as $\%$ surviving cells by setting control cells treated with vehicle as $100 \%$ surviving cells.

Western blot analysis. For western blot analysis, cells were harvested by scraping and dissolved in RIPA (PBS, containing $1 \%$ NP40, $0.5 \%$ sodium deoxycholate, $0.1 \%$ SDS), supplemented with $10 \mu \mathrm{g} / \mathrm{ml}$ phenylmethanesulfonyl fluoride (PMSF). Protein content was determined according to the method of Lowry (25). Equal amounts of total protein lysates were loaded on $10 \%$ SDS-polyacrylamide gels and run at a constant current of $20 \mathrm{~mA}$. Gels were blotted onto nitrocellulose membranes according to the semidry method of Kyhse-Andersen (26). Blots were blocked for $1 \mathrm{~h}$ with TBST (10 mM Tris, $150 \mathrm{mM}$ $\mathrm{NaCl}, 0.05 \%$ Tween-20, pH 8.0), containing 5\% non-fat dry milk. For detection of p-glycoprotein the monoclonal anti-pGp antibody Clone F4 (Sigma-Adrich, Steinheim, Germany) was used. Primary antibodies were incubated overnight at $4{ }^{\circ} \mathrm{C}$, after washing 3 times with TBST, cells were incubated with corresponding secondary antibodies, coupled to horseradish peroxidase for $1 \mathrm{~h}$. After washing once again, detection of bound antibody conjugates was performed with the enhanced chemiluminescence system (ECL, Amersham Biosciences, Freiburg, Germany), according to the manufacturer's protocol.

In vitro invasion and motility assays. 3D invasion in collagen I/ Matrige ${ }^{\circledR}$ gels. Tumour spheroids were generated by seeding 5000 cells/well of Hep2 and Hep2-Tax cells on ultra-lowattachment (ULA) 96-well round-bottomed plates (Corning, Amsterdam, The Netherlands) (27). HLaC79 and HLaC79-Tax cells did not form stable spheroids. After 3-4 days medium 
was replaced by either Matrigel (BD Biosciences, Heidelberg, Germany) or Vitrogen-100 collagen (Cohesion Technologies, Palo Alto, CA, USA) gels, prepared with or without Galium extract $(33.3 \mu \mathrm{l} / \mathrm{ml})$. Matrigel was diluted 1:2 with cell culture medium. Vitrogen-100 gels were supplemented with $10 \% 10 \mathrm{X}$ MEM medium (Life Technologies, Carlsbad, CA, USA) and 5\% Sodium Bicarbonate (Life Technologies, 7.5\% solution for cell culture). Both gels were further supplemented with $25 \mathrm{ng} / \mathrm{ml}$ EGF (Sigma-Aldrich, Taufkirchen, Germany). After solidifying gels at $37^{\circ} \mathrm{C}$ complete medium with or without Galium decoction $(33.3 \mu \mathrm{l} / \mathrm{ml})$ was added on top. Photographs were taken after 1, 24 and $48 \mathrm{~h}$ after embedding with a Leica DMI 4000 inverted fluorescence microscope (Leica Microsystems, Wetzlar, Germany).

Migration on different substrates. For this tumour spheroidbased migration assay, spheroids of Hep2 and paclitaxel-resistant Hep2-Tax spheroids were placed on different extracellular matrix substrates (28). The surface of flat-bottomed 96-well plates were coated with $0.1 \%$ gelatin, $5 \mu \mathrm{g} / \mathrm{ml}$ fibronectin, $50 \mu \mathrm{g} / \mathrm{ml}$ laminin, $50 \mu \mathrm{g} / \mathrm{ml}$ collagen I (all from Sigma-Aldrich, Taufkirchen, Germany) or $125 \mu \mathrm{g} / \mathrm{ml}$ Matrigel (Becton Dickinson, Heidelberg, Germany) for $2 \mathrm{~h}$ at room temperature. Wells were washed twice with PBS and subsequently blocked with $1 \%$ bovine serum albumin in PBS for $1 \mathrm{~h}$. For 2 days on ULA plates pre-cultivated spheroids (see above) of Hep2 and Hep2-Tax cell lines were transferred to the coated wells with a multichannel pipette. Spheroids were incubated with or without Galium decoction $(33.3 \mu \mathrm{l} / \mathrm{ml})$. Migration was recorded by photographing spheroids after 1 and $24 \mathrm{~h}$ with a Leica DMI 4000 inverted fluorescence microscope (Leica Microsystems). Quantification of migrated cells was carried out with ImageJ software (National Institutes of Health, NIH, USA).

MMP-2/MMP-9 gelatin zymography. Cell lines were treated with $33.3 \mu \mathrm{l} / \mathrm{ml}$ Galium verum extract for $48 \mathrm{~h}$. After $48 \mathrm{~h}$, cells were seeded after incubation with Galium extract at equal cell numbers in multiwall plates. Complete medium (MEM or RPMI) was replaced by Optimem (Invitrogen, Karlsruhe, Germany), which is a complete, serum-free medium. Conditioned medium was collected after $18 \mathrm{~h}$. Conditioned (20-60 $\mu \mathrm{l})$ medium was directly subjected to electrophoresis in $10 \%$ SDS-polyacrylamide gels under non-reducing conditions (29), containing $1 \mathrm{mg} / \mathrm{ml}$ gelatin (Sigma-Aldrich, Traunstein, Germany). After electrophoresis, gels were renaturated two times for $30 \mathrm{~min}$ in $2.5 \%$ Triton $\mathrm{X}-100$ and developed overnight in developing solution (50 mM Tris.HCl, pH 6.8, 0.2 M $\mathrm{NaCl}, 10 \mathrm{mM} \mathrm{CaCl}, 0.02 \%$ Brij 35) at $37^{\circ} \mathrm{C}$. Subsequently they were stained with Coomassie Brilliant Blue, destained and dried.

Tube formation assay. Using tube formation assays, the ability of endothelial cells to form three-dimensional capillary-like structures was analyzed. Angiogenesis-slides (15-well, Ibidi $\mathrm{GmbH}$, Munich, Germany) were coated with growth factor reduced basement membrane extract (BME; Trevigen, MD, USA). After polymerization of BME, the gels were overlaid with growth medium containing $1 \times 10^{4}$ HUVECs and the $33.3 \mu \mathrm{l} / \mathrm{ml}$ Galium extract. Cells were incubated for $6-8 \mathrm{~h}$ and images were taken. Evaluation of pictures was performed by
Wimasis GmbH (Munich, Germany). For quantification, four parameters were analyzed: tube length, number of branching points, covered area and number of loops.

cDNA expression array. RNA extraction and RNA quality control. RNA of Galium-treated and untreated cell lines Hep2 and HLaC79 (48 h, $33.3 \mu \mathrm{l} / \mathrm{ml})$ was isolated with the RNeasy kit (Qiagen, Hilden, Germany) according to the manufacturers instructions. RNA quality was assessed with the RNA 6000 Nano kit using the Bioanalyzer 2100 instrument (Agilent, Böblingen, Germany). RNA integrity numbers (RINs) of our samples ranged between 9.4 and 9.9 .

Microarray hybridization. For microarray hybridization, $100 \mathrm{ng}$ total RNA were amplified and labelled using the IVT Express kit and hybridized to GeneChip PrimeView Human Gene Expression arrays (both from Affymetrix, Santa Clara, CA, USA). Microarray washing and staining was performed with a Fluidics Station 450; fluorescence intensities were scanned with a GeneChip Scanner 3000 7G (both from Affymetrix). Image processing (microarray grid definition, feature intensity readout) and CEL file generation was achieved with the GeneChip Operating Software (Affymetrix).

Microarray evaluation. Raw microarray data were background corrected, normalized and summarized to probe-set expression values using the Robust Microarray Average (RMA) algorithm $(30,31)$. For each cell line differentially expressed probe-sets resulting from treatment were detected in each cell line by estimating the false discovery rate (FDR) with an empirical Bayesian methodology employing a lognormal normal data modeling (32). Significant $($ FDR $<0.05)$ probe-sets were subjected to gene set enrichment analysis using DAVID (33). These analyses were performed in the R environment (http://www.r-project.org) using Bioconductor (http://www.bioconductor.org) packages 'affy' and 'EBarrays'.

Real-time PCR. To verify results of arrays, quantitative realtime Taqman ${ }^{\mathrm{R}}$ PCR (AppliedBiosystems.com) was performed. Different cell lines (Hep2, Hep2-Tax, HLaC79, HLaC79-Tax, Fadu) were treated for $48 \mathrm{~h}$ with Galium verum decoction $(33.3 \mu \mathrm{l} / \mathrm{ml})$ or vehicle. Subsequently cells were rinsed with phosphate buffered saline (PBS; $137 \mathrm{mM} \mathrm{NaCl}, 2.7 \mathrm{mM} \mathrm{KCl}$, $10 \mathrm{mM} \mathrm{Na} \mathrm{HPO}_{4} \cdot 2 \mathrm{H}_{2} \mathrm{O}, 2 \mathrm{mM} \mathrm{KH_{2 }} \mathrm{PO}_{4}, \mathrm{pH}$ 7.4) and scraped off for RNA isolation, which was performed with the RNeasy kit (Qiagen) according to the manufacturer's instructions. The High Capacity RNA-to-cDNA Master Mix (Applied Biosystems, Darmstadt, Germany) was used for cDNA reverse transcription. Real-time PCR was performed in triplicates on a Real-time PCR cycler (Applied Biosystems) using Taqman Gene expression assays for MDR-1, TXNIP, MDM2, JUN, MMP-10 and RND3. Relative quantification was calculated according to the $2^{-\Delta \Delta C T}$ method (34). Expression values were normalized to the expression of GAPDH as an endogenous control which proved to be expressed most stably throughout the cell lines.

Statistical analysis. All statistical analyses and graphs were performed with Graph Pad Prism 4 (Graphpad software, La Jolla, CA, USA) 

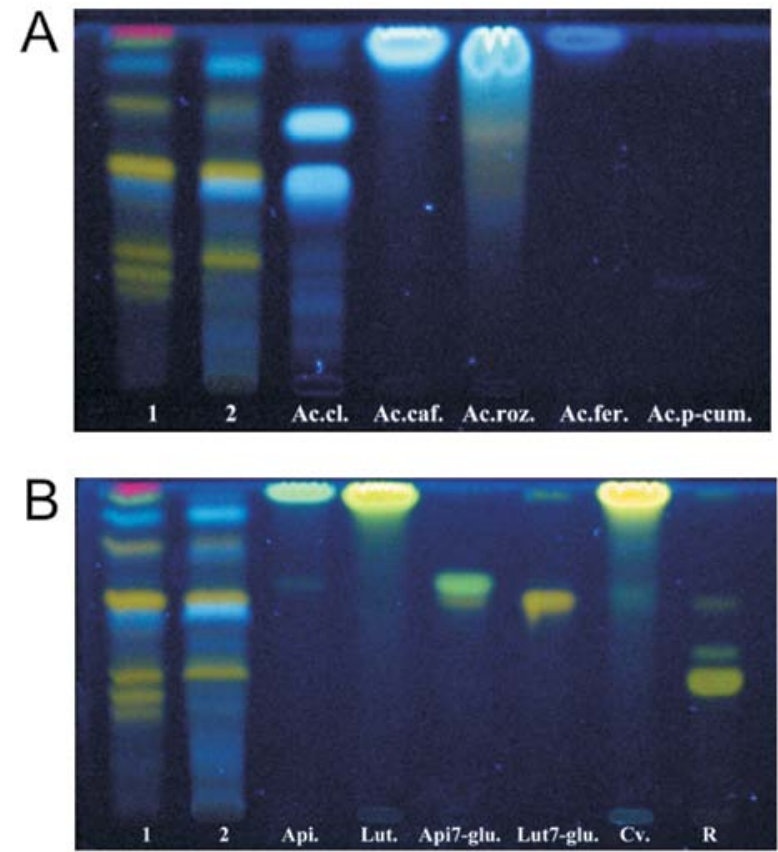

Figure 1. (A) TLC chromatogram for polyphenolic acids of Galium verum samples. Galium verum - alcoholic extract (1), Galium verum - aqueous extract (2), Standards: chlorogenic acid (Ac.cl.), caffeic acid (Ac.caf.), rosmarinic acid (Ac.roz.), ferulic acid (Ac.fer.), p-coumaric acid (Ac.p-cum.). (B) TLC chromatogram for flavons of Galium verum samples. Galium verum - alcoholic extract (1), Galium verum - aqueous extract (2), Standards: apigenol (Api.), luteolin (Lut.), apigenol-7-O-glucoside (Api7-glu), luteolin7O-glucoside (Lut7-glu), quercetol (Cv), rutoside (R).

\section{Results}

Galium verum decoction: sample identification by thin layer chromatography (TLC). Qualitative phytochemical analysis for the Galium verum decoction in comparison to a known Galium verum methanolic extract (24) was performed by thin layer chromatography, in order to determine the biologically active compounds (polyphenolcharboxylic acids and flavons).

Chromatographic images with polyphenolcarboxylic acid standards clearly demonstrate the presence of chlorogenic acid in both extracts, more pronounced in the aqueous extract (Fig. 1). Luteolin-7-O-glucoside and rutoside (Fig. 2) are present in pronounced amounts in the flavonoid fraction of the aqueous Galium extract.

Multidrug resistance. Expression of P-Gp in Hep2, Hep-2-Tax, HLaC79 and HLaC79-Tax was tested by western blot analysis of whole cell lysates and by Taqman qRT-PCR. Both methods confirmed overexpression of P-Gp in HLaC79-Tax and Hep2-Tax cell lines. Lowest amount of the mdr-1 transcript was detected in HLaC79 cells (Fig. 2). Adequate protein bands in western blots were clearly visible in the paclitaxel-resistant clones Hep-2-Tax and HLaC79-Tax. Weak signals came up in HLaC79 and Hep2 protein lysates (Fig. 2).

Cytotoxicity. The four cell lines were treated with increasing concentrations of Galium aqueous extract. Cell viability and cytotoxicity of the used drugs were measured with the MTT assay. Mean percentage inhibition was calculated from at least three independent experiments. Galium extract significantly

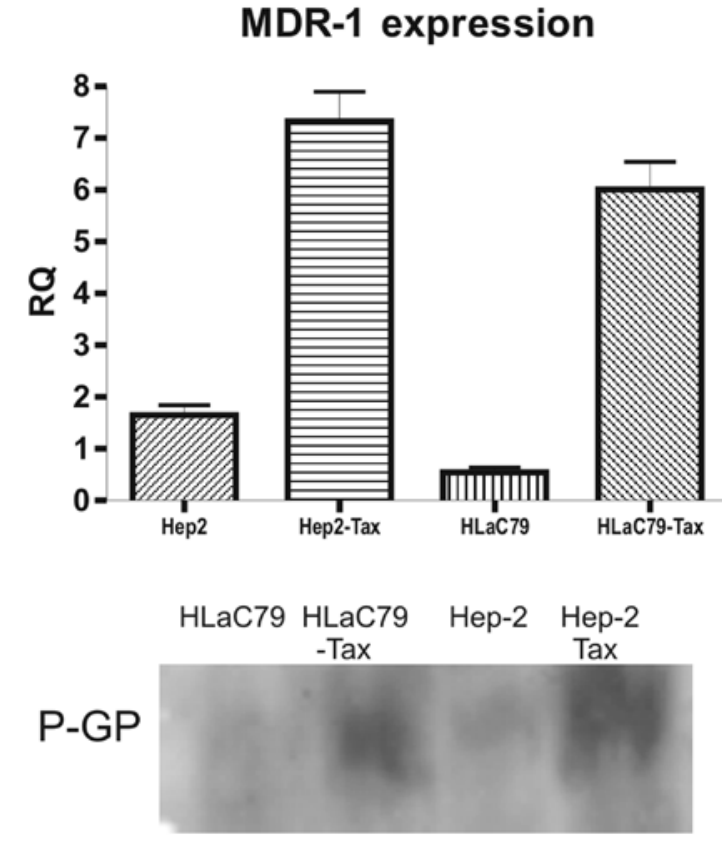

Figure 2. Expression of P-glycoprotein mRNA, measured by Taqman qRT-PCR. RQ $=2^{-\Delta \Delta C T}$. Values are $\pm S E$ and normalized to the expression of GAPDH. Results are confirmed by western blot analysis of total cell lysates of HLaC79, HLaC79-Tax, Hep2 and Hep2-Tax cell lines.

suppressed the growth of all cell lines (Kruskal-Wallis-test, $\mathrm{p}<0.05)$. The multidrug resistant clones of HLaC79 and Hep2, however, tolerated high Galium concentrations better than the parental drug-sensitive cell lines (Fig. 3).

Motility. 3D invasion in semisolid gels. Investigation of invasion and motility experiments was carried out using spheroid-based experiments. First these experiments better reflect the solid tumour-microenvironment interaction. Second the widely used Boyden Chamber assay proved to be not reproducible in the actual system.

Spheroids of all for cell lines were grown in ultra-lowattachment-plate (ULA-plate) wells. While Hep2 and Hep2-Tax cells formed round-shaped compact spheroids, HLaC79 cells produced only loose aggregates, resolving on pipetting. In contrast to all other cell lines HLaC79-Tax cells did not even form loose aggregates. Instead, many tiny spheroids appeared within the ULA wells, with cells only loosely attached to each other (Fig. 4). For this reason the examinations were limited to Hep2 and Hep2-Tax cells for detailed motility and invasion experiments. Galium decoction was used at a concentration of $33.3 \mu \mathrm{l} / \mathrm{ml}$ which proved to be not lethal to the cell lines.

When embedding Hep2/Hep2-Tax spheroids into solidified Matrigel, with or without EGF, the cells tended not to invade gels. In collagen gels, however, cells did invade. Hep2-Tax cell migration was stronger than the chemosensitive original Hep2 cells (Fig. 5). This mode of invasion was inhibited by Galium extract within collagen gels.

Cell migration on extracellular Matrix (ECM) proteins. For quantification of invasion on different ECM substrates Hep2 and Hep2-Tax spheroids were transferred manually to wells, coated with gelatine, fibronectin, laminin, collagen I or matrigel. Images of the cells were taken after attachment to 


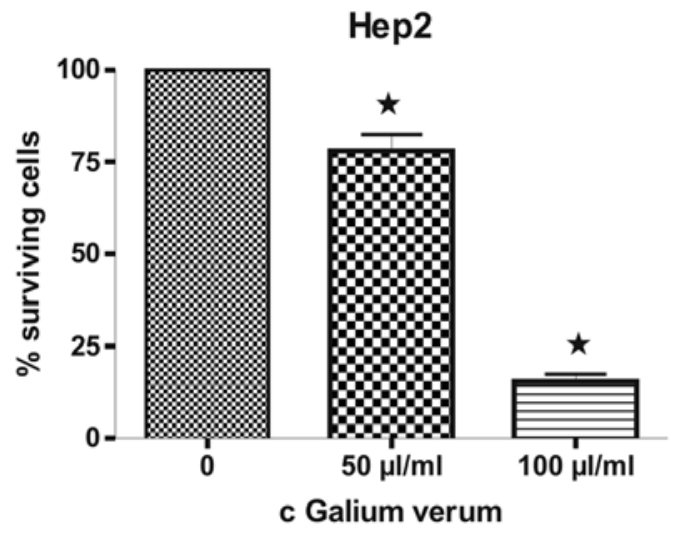

HLaC79

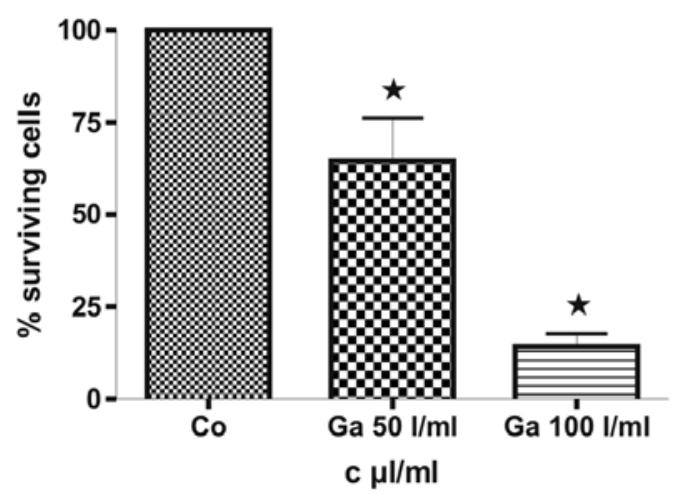

Hep2-Tax

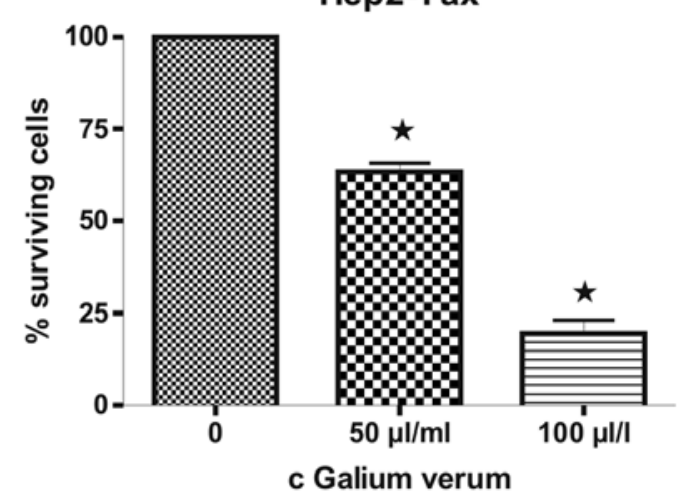

HLaC79-Tax

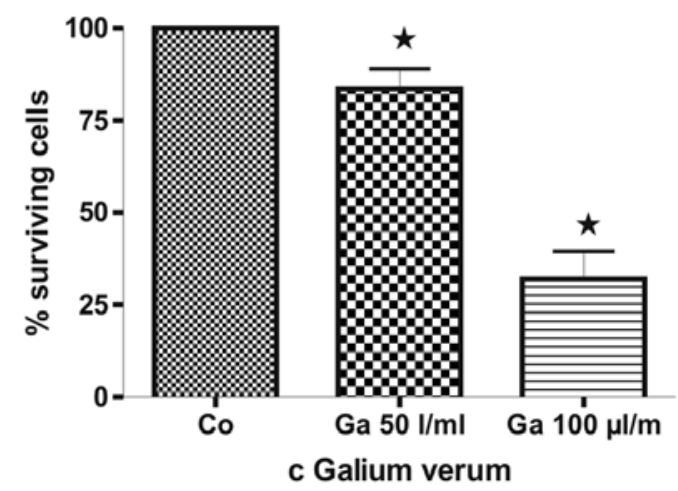

Figure 3. Cytotoxicity of Galium decoction on chemosensitive (Hep2, HLaC79) and chemoresistant (HLaC79-Tax, Hep2-Tax) cell lines, measured with the MTT assay. ("p $<0.05$; Kruskal-Wallis test).
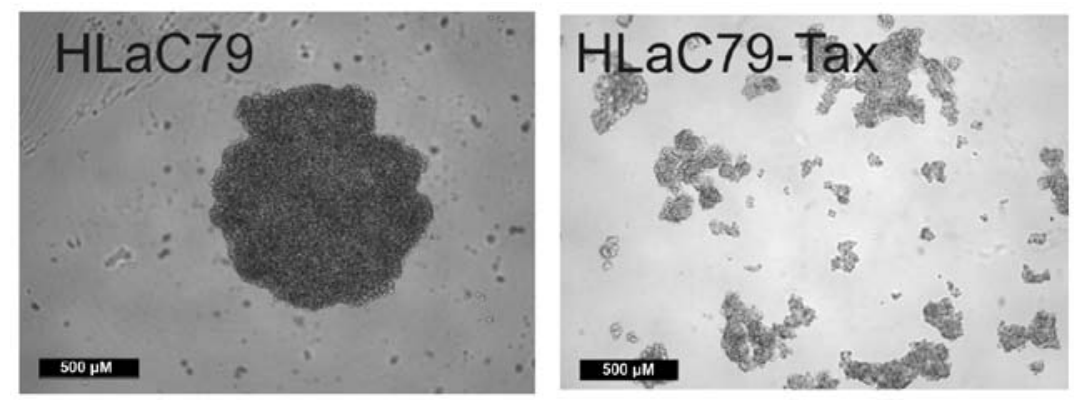

Figure 4. Spheroids produced from HLaC79 and HLaC79-Tax cell lines by growing 5,000 cells/well in ULA-plates.

ECM $(\mathrm{t}=0)$ and after $24 \mathrm{~h}(\mathrm{t}=24)$. For quantification of cells migrating out of spheroids the areas of spheroids at $t=0$ were substracted from areas measured after $24 \mathrm{~h}$, using Image J software (Fig. 6).

For evaluation of cell motility the area at $\mathrm{t}=0$ was set at $100 \%$. The percentage of the migrated area was calculated as the following formula:

$$
\begin{gathered}
\% \text { migrated area }=\frac{100 \times \Delta \text { Area }}{\text { Area }^{\mathrm{t}=0}} \\
\text { whereas } \Delta \text { Area }=\text { Area }^{\mathrm{t}=24}-\text { Area }^{\mathrm{t}=0}
\end{gathered}
$$

Migration of Hep2 and Hep2-Tax cells on gelatin, fibronectin, laminin, collagen I and Matrigel substrate with or without Galium was measured. Representative examples for Hep2 and
Hep2-Tax cells migrating on collagen I and Matrigel with or without Galium are shown in Fig. 7. Invasion patterns on gelatin, fibronectin and laminin showed a similar optical appearance, although percentage invasion differed notably between the substrates (Fig. 8). Highest motility was observed on Matrigel substrate in chemosensitive as well as in chemoresistant cells.

Comparing percentage of the migrated areas of Hep2 and Hep2-Tax cell lines revealed higher motility in chemoresistant Hep2-Tax cells, albeit statistically significant only for laminin and collagen I (unpaired t-test, $\mathrm{p}<0.05$, Fig. 8) with fibronectin as an exception, where both cell lines migrated approximately equal. Additionally invaded areas between vehicle- and Galium-treated spheroids were compared. Results are shown in Fig. 9. 


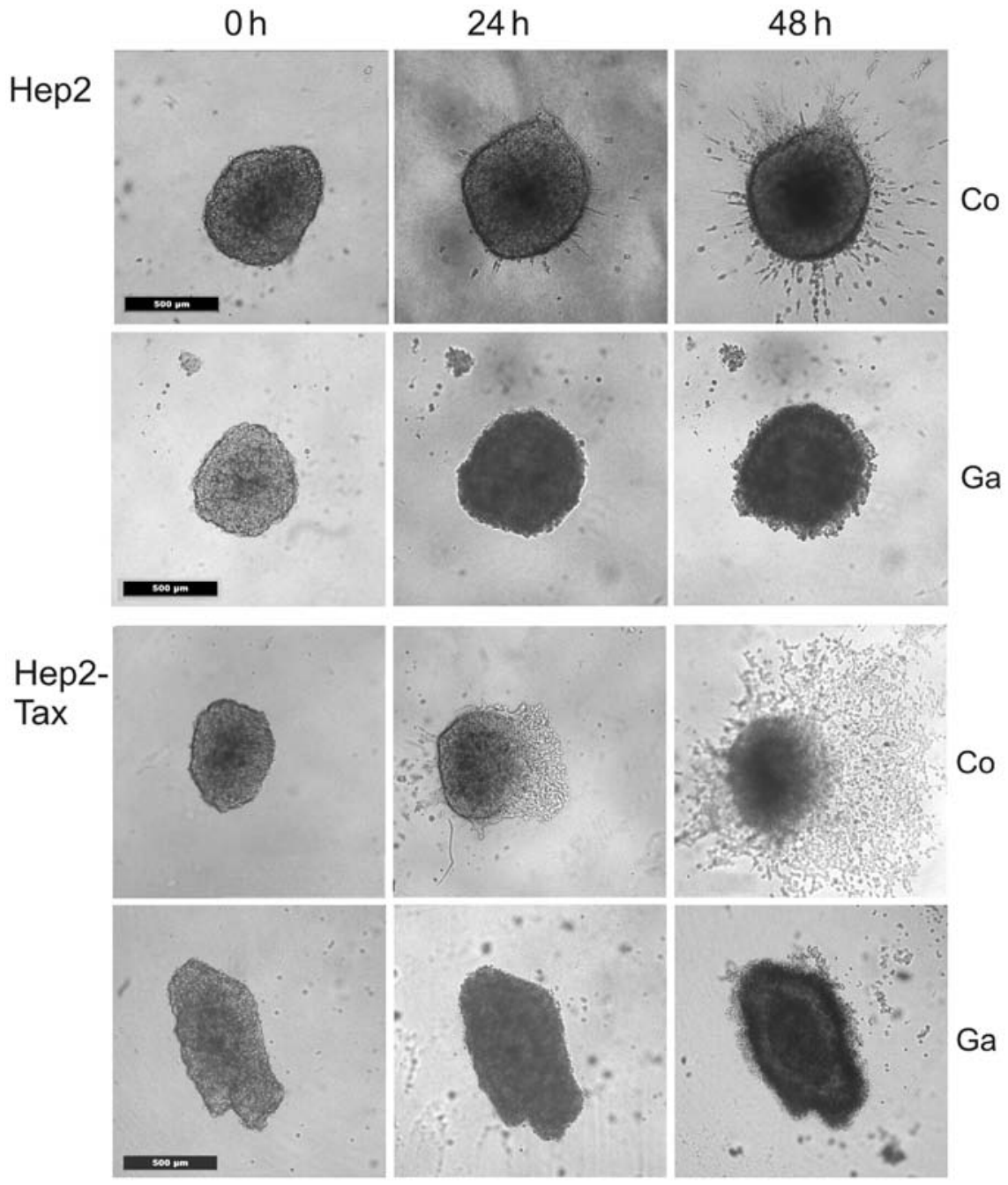

Figure 5. Three-dimensional migration of spheroid cells into Collagen gels with (Ga) or without (Co) Galium aqueous extract. Images were taken at 0, 24 and $48 \mathrm{~h}$ after embedding.
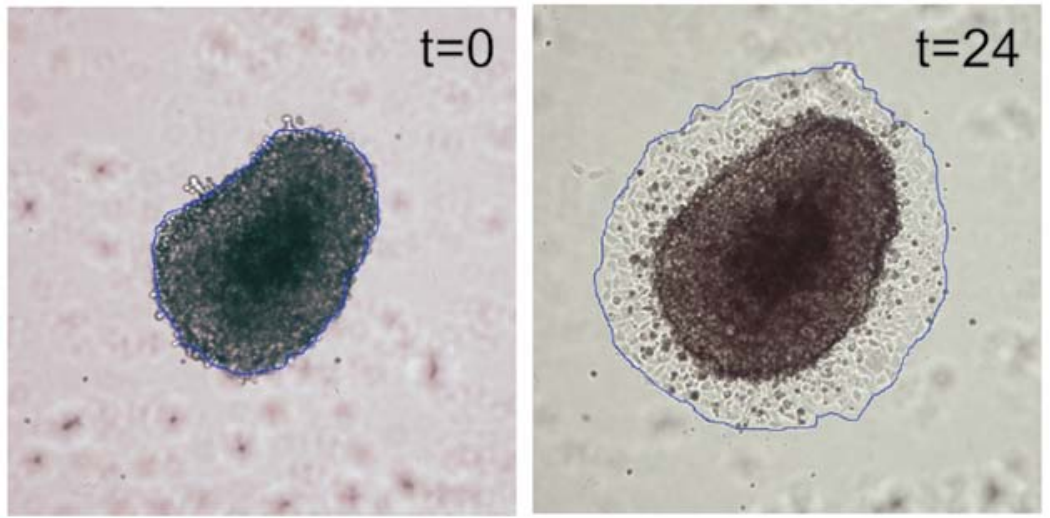

Figure 6. Measurement of invaded areas with ImageJ. For evaluation of cell motility the area at $\mathrm{t}=0$ was set at $100 \%$. The percentage of the migrated area was calculated as described in the Results.

In both cell lines ECM substrate invasion was inhibited significantly by Galium verum decoction at sublethal doses of $33.3 \mu \mathrm{l} / \mathrm{ml}$ (unpaired t-test, $\mathrm{p}<0.05$ ). Comparison of the percentage reduction of migrated area caused by Galium in the two cell lines revealed a stronger inhibition of invasion in the aggressively invading chemoresistant Hep2-Tax cells (Table I).
Gelatinolytic activity. Gelatinolytic activity of Galium-treated cell lines was examined using gelatin zymography. Culture supernatants of Hep2, Hep2-Tax, HLaC79 and HLaC79-Tax cells, treated with sublethal doses of Galium or vehicle were separated and developed on gelatin zymographic gels. Results are shown in Fig. 10. Gelatinolytic activity of the active 

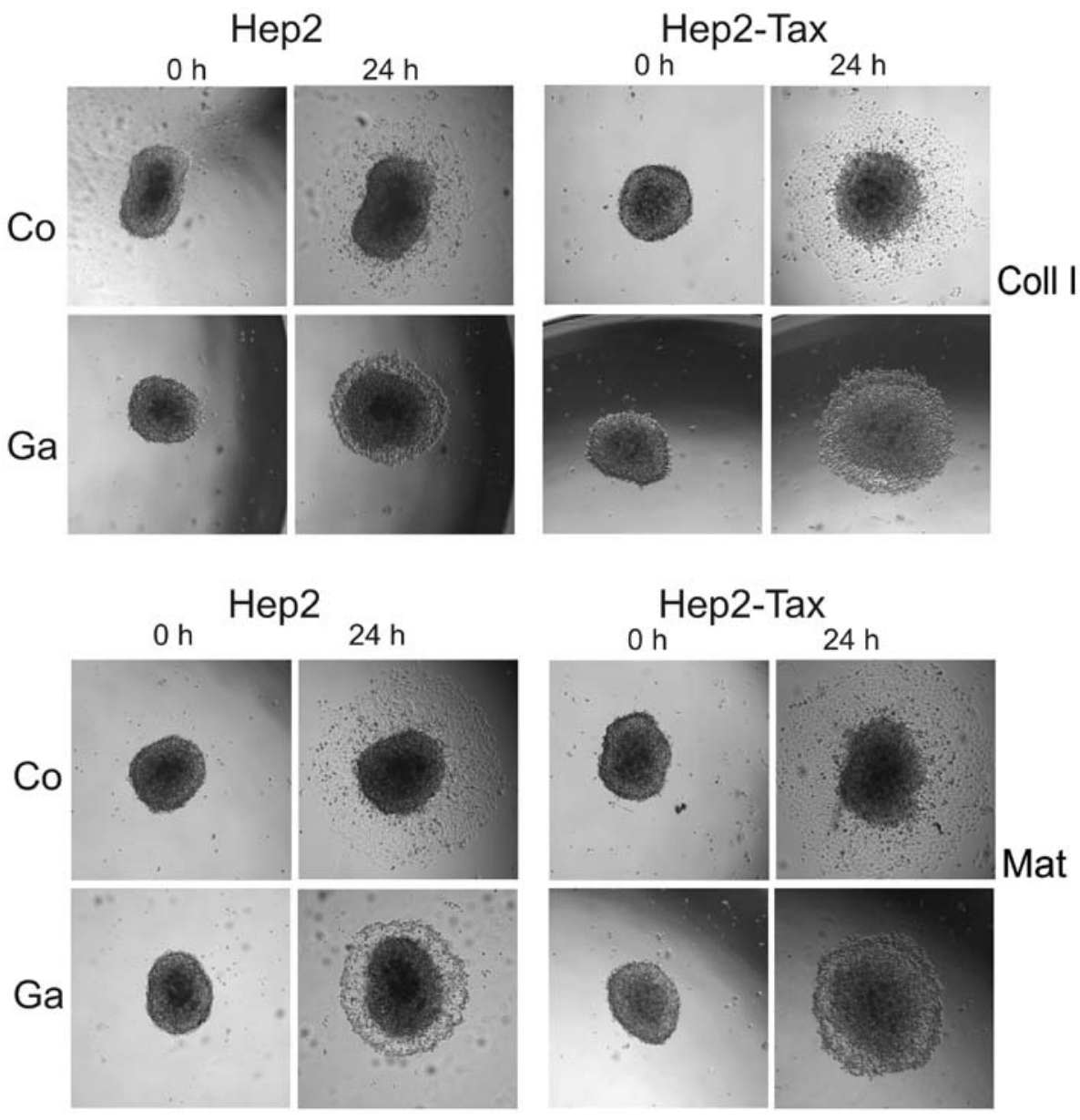

Figure 7. Invasion patterns of Hep2 and Hep2-Tax cells on Collagen I (CollI) or Matrigel ${ }^{\circledR}$ (Mat) coated surfaces at $\mathrm{t}=0$ ( $(0 \mathrm{~h}$ after transfer to substrate) and $\mathrm{t}=24$ (24 h later) with (Ga) or without (Co) Galium verum aqueous extract.

\section{Invasion Hep2 vs. Hep2-Tax}

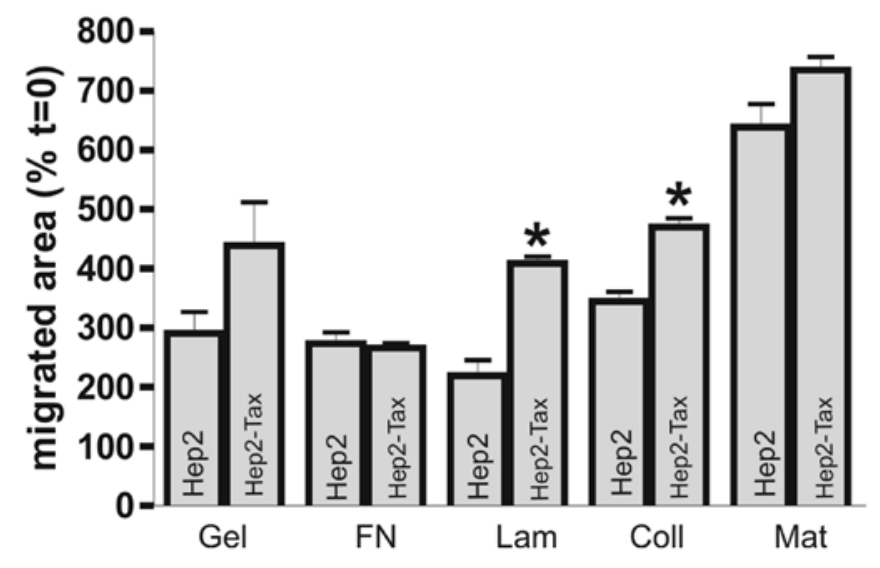

Figure 8. Percentage of invasion of Hep2 or Hep2-Tax cells on different substrates (Gel, Gelatin; FN, Fibronectin; Lam, Laminin; Coll, Collagen I; Mat, Matrigel). Statistically significant values are marked with an asterisk (unpaired t-test, $\mathrm{p}<0.05$ ).

$66 \mathrm{kDa}$ MMP-2 was diminished in the cell lines HLaC79, Hep2 and HLaC79-Tax by Galium decoction treatment. In the paclitaxel-resistant clone Hep2-Tax no effect of Galium treatment on gelatinolytic activity was detectable.
Table I. Percentage reduction of invasion caused by Galium verum aqueous extract in Hep2 and Hep2-Tax cell lines. ${ }^{\mathrm{a}}$

\begin{tabular}{lcc}
\hline & \multicolumn{2}{c}{$\begin{array}{c}\text { Inhibition of invasion } \\
\text { Co vs. Ga-treated (\%) }\end{array}$} \\
\cline { 2 - 3 } & \multicolumn{1}{c}{ Hep2 } & Hep2-Tax \\
\hline Gelatin & $60.75 \pm 13.55$ & $102.39 \pm 39.43$ \\
Fibronectin & $77.25 \pm 26.83$ & $109.00 \pm 15.03$ \\
Laminin & $95.00 \pm 28.84$ & $197.30 \pm 21.17$ \\
Collagen I & $159.70 \pm 23.83$ & $273.80 \pm 16.36$ \\
Matrigel $^{\circledR}$ & $368.00 \pm 45.52$ & $503.00 \pm 36.32$
\end{tabular}

${ }^{\text {aD }}$ ata are based on the percentage invasion difference between the means of untreated and Galium-treated spheroids, calculated by GraphPad 4.

Angiogenesis. Effects on angiogenesis were tested with the tube formation assay, quantifying total tube length, total branching points, total loops and \% covered area. There was no statistical significant or visible influence of Galium extracts at 33.6 or $66.6 \mu \mathrm{l} / \mathrm{ml}$ on tube formation of HUVECs growing on Matrigel (Fig. 11, here shown for $66.6 \mu \mathrm{l} / \mathrm{ml}$ ). 


\section{Hep2}
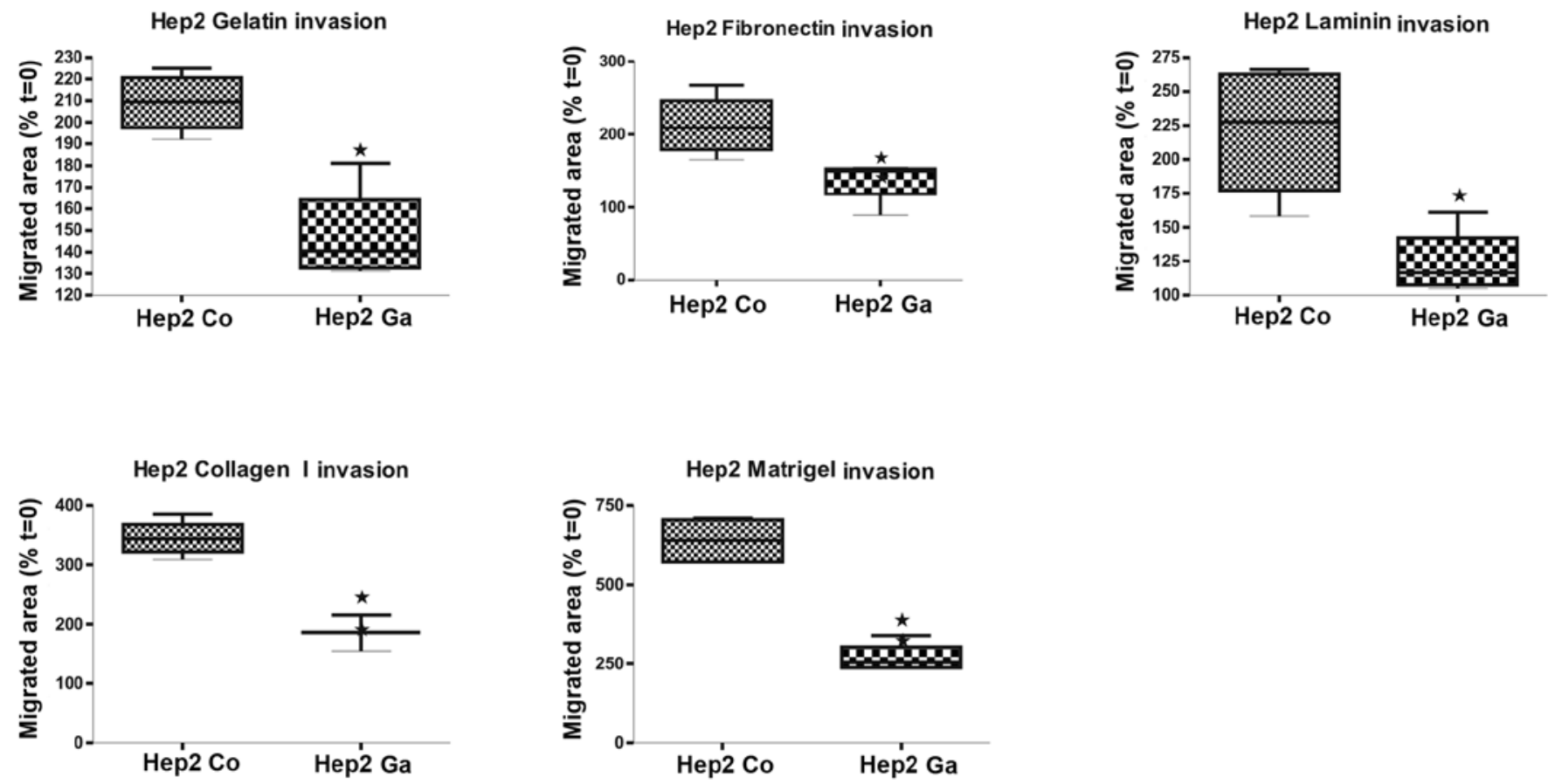

\section{Hep2-Tax}
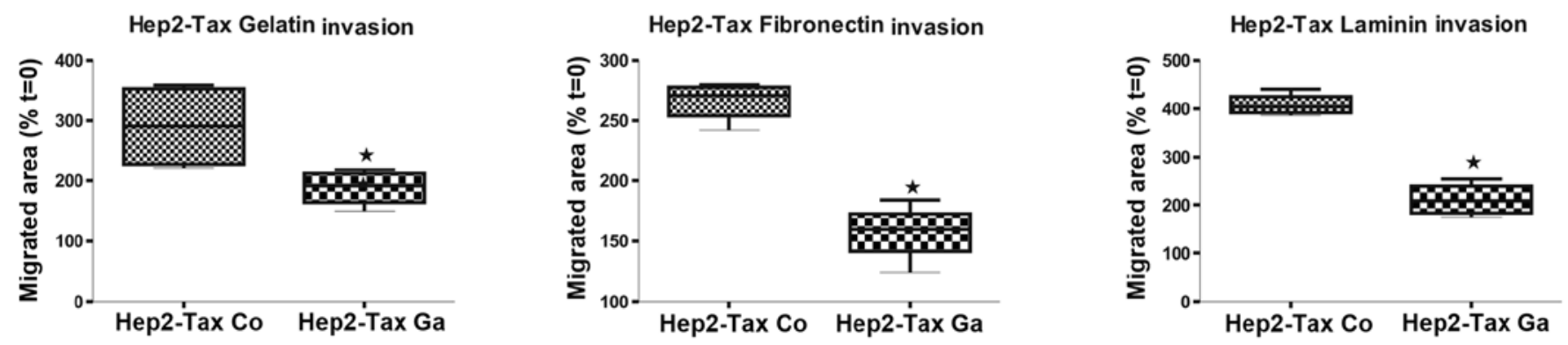

Hep2-Tax Collagen Iinvasion
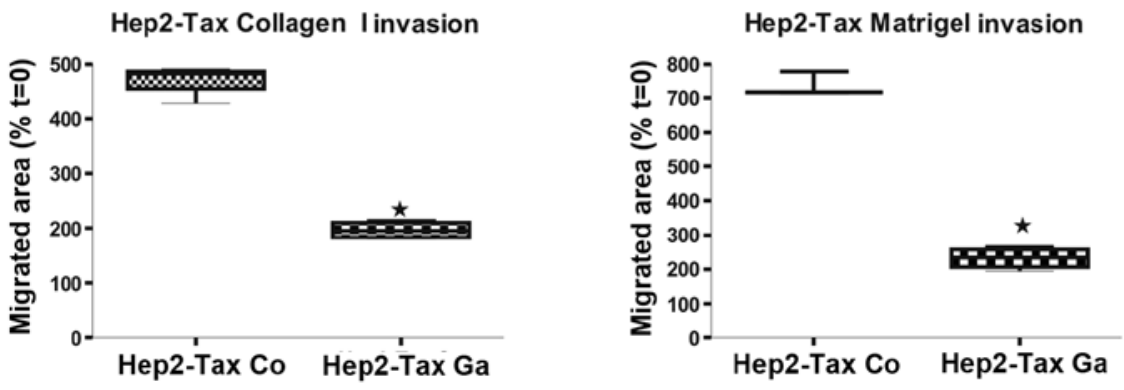

Figure 9. Inhibition of substrate invasion by Galium aqueous extract. Hep2 and Hep2-Tax cell lines with (Ga) or without Galium (Co) extract on Gelatin-, Fibronectin-, Laminin-, Collagen I- and Matrigel ${ }^{\circledast}$-coated surfaces were tested. Statistically significant values are marked with an asterisk (unpaired t-test, $\mathrm{p}<0.05)$.

cDNA array. Using the PrimeView Human Gene Expression array (Affymetrix), the expression profiles of two cell lines (HLaC79 and Hep2) following a Galium treatment $(33.3 \mu \mathrm{l} / \mathrm{ml}$, $48 \mathrm{~h}$ ) in comparison to untreated cells were created. Of 48,736 analyzed genes, 367 were significantly differentially expressed in Hep2 cells and 279 in HLaC79 cells following Galium treatment. There were only 11 genes affected significantly in both cell lines (Table III) in this experiment, indicating that the effect of this cocktail of active substances is dependent on cell type and/or cell status (cell cycle, passage number, gene expression profile, differentiation and/or hormonal stage).

The most differentially expressed genes for both cell lines are listed in Table II. For both cell lines, significantly up/ downregulated genes are listed in Table III. AKR1C1 and C3 
Table II. The most significant up/downregulated genes in Hep2 and HLaC79 cell lines caused by treatment with $33.3 \mu 1 / \mathrm{ml}$ Galium verum decoction for $48 \mathrm{~h} .^{\mathrm{a}}$

\begin{tabular}{|c|c|c|c|}
\hline Gene symbol & Gene name & Function & $\log \mathrm{FC}$ \\
\hline \multicolumn{4}{|c|}{ HLaC79: Galium responding genes } \\
\hline PHB2 & Prohibitin 2 & Negative regulation of gene expression & 3.10 \\
\hline JUN & Jun proto-oncogene & Apoptosis, protein targeting & -3.09 \\
\hline TMED3 & $\begin{array}{l}\text { Transmembrane emp } 24 \text { protein } \\
\text { Transport domain containing } 3\end{array}$ & Protein regulation & 3.03 \\
\hline INHBE & Inhibin, $\beta E$ & Hormone & -3.01 \\
\hline TFRC & Transferrin receptor $(\mathrm{p} 90, \mathrm{CD} 71)$ & Membrane organisation, vesicle transport & 2.95 \\
\hline $\begin{array}{l}\text { HSPA8/SNORD14C/ } \\
\text { SNORD14D }\end{array}$ & $\begin{array}{l}\text { Heat shock } 70 \mathrm{kDa} \text { protein } 8 / \text { small nucleolar } \\
\text { RNA, C/D box } 14 \mathrm{C} / 14 \mathrm{D}\end{array}$ & Protein folding, vesicle transport & 2.91 \\
\hline ARL6IP4 & $\begin{array}{l}\text { ADP-ribosylation-like factor } 6 \\
\text { interacting protein } 4\end{array}$ & mRNA splicing regulation (?) & 2.68 \\
\hline FNDC3B & Fibronectin type III domain containing 3B & Fat cell differentiation & -2.61 \\
\hline SNRPB & $\begin{array}{l}\text { Small nuclear ribonucleoprotein } \\
\text { polypeptides B and B1 }\end{array}$ & mRNA splicing & 2.49 \\
\hline PTPRM & Protein tyrosine phosphatase, receptor type, $\mathrm{M}$ & Cell migration & -2.48 \\
\hline $\begin{array}{l}\text { LOC } 100652805 / \\
\text { 100653302/PGK1 }\end{array}$ & $\begin{array}{l}\text { Uncharacterized LOC100652805/100653302/ } \\
\text { phosphoglycerate kinase } 1\end{array}$ & Energy metabolism & 2.45 \\
\hline ARHGAP29 & Rho GTPase activating protein 29 & Small GTPase mediated signal transduction & -2.42 \\
\hline RBBP4 & Retinoblastoma binding protein 4 & $\begin{array}{l}\text { Chromatin remodeling, } \\
\text { transcriptional repression }\end{array}$ & 2.41 \\
\hline $\mathrm{LMO} 2$ & LIM domain only 2 (rhombotin-like 1) & $\begin{array}{l}\text { Negative regulation of } \\
\text { cell differentiation }\end{array}$ & -2.40 \\
\hline SNAP91 & $\begin{array}{l}\text { Synaptosomal-associated protein, } \\
91 \mathrm{kDa} \text { homolog (mouse) }\end{array}$ & $\begin{array}{l}\text { Cellular protein complex assembly, } \\
\text { vesicle transport }\end{array}$ & -2.35 \\
\hline MMP10 & Matrix metallopeptidase 10 (stromelysin 2) & Invasion, motility & -2.35 \\
\hline SHMT2 & $\begin{array}{l}\text { Serine hydroxymethyltransferase } 2 \\
\text { (mitochondrial) }\end{array}$ & $\begin{array}{l}\text { Mitochondrial thymidylate } \\
\text { biosynthesis pathway }\end{array}$ & 2.31 \\
\hline DCLRE1C & DNA cross-link repair $1 \mathrm{C}$ & Recombination, DNA repair & 2.30 \\
\hline PTPRM & Protein tyrosine phosphatase, receptor type, M & Cell migration & -2.29 \\
\hline ACTG1 & Actin, $\gamma 1$ & Cytoskeleton organization, cell motion & 2.30 \\
\hline ZNF511 & Zinc finger protein 511 & Transkriptional regulation (?) & 2.26 \\
\hline XYLT1 & Xylosyltransferase I & Biosynthesis of glycosaminoglycan & -2.24 \\
\hline NRCAM & Neuronal cell adhesion molecule & $\begin{array}{l}\text { Extracellular structure organization, } \\
\text { cell motion/adhesion }\end{array}$ & -2.17 \\
\hline RUFY3 & RUN and FYVE domain containing 3 & Negative regulation of cell differentiation & -2.16 \\
\hline SATB1 & SATB homeobox 1 & Negative regulation of gene expression & -2.12 \\
\hline NF1 & Neurofibromin 1 & Cytoskeleton organization, tumor suppressor & -2.12 \\
\hline TRAPPC6B & Trafficking protein particle complex $6 \mathrm{~B}$ & Vesicle mediated transport & -2.09 \\
\hline CDS1 & $\begin{array}{l}\text { CDP-diacylglycerol synthase } \\
\text { (phosphatidate cytidylyltransferase) } 1\end{array}$ & Phosphatidylinositol biosynthesis & -2.09 \\
\hline CPSF6 & $\begin{array}{l}\text { Cleavage and polyadenylation specific } \\
\text { factor } 6,68 \mathrm{kDa}\end{array}$ & Pre-mRNA 3'-processing & 2.11 \\
\hline
\end{tabular}

EDARADD/ENO1 EDAR-associated death domain/enolase 1, $(\alpha)$

Ectoderm-mesoderm interactions/glycolysis 
Table II. Continued

\begin{tabular}{lll}
\hline Gene symbol & Gene name & Function \\
\hline
\end{tabular}

Hep2: Galium responding genes

AKR1C2

HMOX1

TXNIP

IFIT2

MDM2

AKR1C1

ASZ1

CCPG1

AKR1C3

ENY2

CDC42EP3

BST1

HEXIM1

RBM15

LOC100505861/

TPRG1

NEDD9

DHRS2

SRP19

MED18

IGSF10

HSPA5

PDP1

MAT2A

PHLDA1

RND3

HIST1H2BC/

$\mathrm{BE} / \mathrm{BF} / \mathrm{BG} / \mathrm{BI}$

\section{LARP6}

DYNLL2

USP47

MKI67
Aldo-keto reductase family 1 , member $\mathrm{C} 2$

Heme oxygenase (decycling) 1

Thioredoxin interacting protein

Interferon-induced protein with tetratricopeptide repeats 2

Mdm2, p53 E3 ubiquitin protein ligase homolog (mouse)

Aldo-keto reductase family 1 , member $\mathrm{C} 1$

Ankyrin repeat, SAM and basic/l eucine zipper domain containing 1

Cell cycle progression 1

Aldo-keto reductase family 1 , member C3

Enhancer of yellow 2 homolog (Drosophila)

CDC42 effector protein (Rho GTPase binding) 3

Bone marrow stromal cell antigen 1

Hexamethylene bis-acetamide inducible 1

RNA binding motif protein 15

Uncharacterized LOC100505861/

tumor protein $\mathrm{p} 63$ regulated 1

Neural precursor cell expressed, developmentally downregulated 9

Dehydrogenase/reductase (SDR family) member 2

Signal recognition particle $19 \mathrm{kDa}$

Mediator complex subunit 18

Immunoglobulin superfamily, member 10

Heat shock $70 \mathrm{kDa}$ protein 5

Pyruvate dehyrogenase phosphatase catalytic subunit 1

Methionine adenosyltransferase II, $\alpha$

Pleckstrin homology-like domain, family A, member 1

Rho family GTPase 3

Histone cluster 1, H2bc, H2be, H2bf, H2bg, H2bi

La ribonucleoprotein domain family, member 6

Dynein, light chain, LC8-type 2

Ubiquitin specific peptidase 47

Antigen identified by monoclonal antibody Ki-67
Xenobiotics metabolism

4.46

Regulation apoptosis, ARE pathway

4.25

Regulation apoptosis, drug

response, tumor suppressor

Interferon signalling

Cell cycle

Xenobiotics metabolism

Drug response

Cell cycle

Xenobiotics metabolism

3.28

Chromosome organisation

3.22

Transcription activation

$-2.98$

Estrogen receptor signalling

Chromatin organisation (?)

Cell cycle

Regulation of apoptosis

Drug response

Transcription activation

$-2.68$

$-2.67$

Regulation of apoptosis

$-2.66$

Protein amino acid

dephosphorylation

Drug response

Regulation of apoptosis

Cell cycle

Cellular macromolecular

complex assembly

Tumor suppressor

Cell cycle 
Table III. Significantly up/downregulated genes in both Hep2 and HLaC79 cell lines caused by treatment with $33.3 \mu 1 / \mathrm{ml}$ Galium verum decoction for $48 \mathrm{~h}$.

\begin{tabular}{|c|c|c|c|}
\hline Gene symbol & Gene name & Hep2 & HLaC79 \\
\hline AKR1C3 & $\begin{array}{l}\text { Aldo-keto reductase family } 1 \text {, member C } 3 \text { ( } 3 \text { - } \alpha \text { hydroxysteroid } \\
\text { dehydrogenase, type II) }\end{array}$ & + & - \\
\hline ID1 & Inhibitor of DNA binding 1, dominant negative helix-loop-helix protein & - & - \\
\hline PIR & Pirin (iron-binding nuclear protein) & + & + \\
\hline HES1 & Hairy and enhancer of split $1,($ Drosophila $)$ & + & - \\
\hline FNDC3B & Fibronectin type III domain containing 3B & - & - \\
\hline AKR1C1 & $\begin{array}{l}\text { Aldo-keto reductase family } 1 \text {, member } \mathrm{C} 1 \text { (dihydrodiol dehydrogenase } 1 \text {; } \\
20-\alpha(3-\alpha) \text {-hydroxysteroid dehydrogenase) }\end{array}$ & + & - \\
\hline ENSA & Endosulfine $\alpha$ & - & - \\
\hline ZNF789 & Zinc finger protein 789 & + & + \\
\hline ARHGAP26 & Rho GTPase activating protein 26 & - & - \\
\hline $\begin{array}{l}\text { CCPG1 /// } \\
\text { DYX1C1-CCPG1 }\end{array}$ & Cell cycle progression $1 / / /$ DYX1C1-CCPG1 readthrough (non-protein coding) & - & - \\
\hline $\begin{array}{l}\text { CARD16 /// } \\
\text { CAS31 }\end{array}$ & $\begin{array}{l}\text { Caspase recruitment domain family, member } 16 / / / \text { caspase } 1 \text {, } \\
\text { apoptosis-related cysteine peptidase }\end{array}$ & - & - \\
\hline
\end{tabular}

+ , upregulation; -, downregulation.

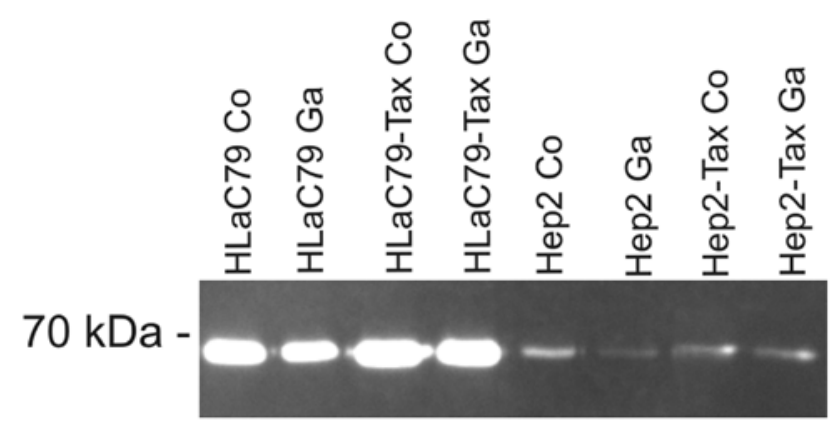

Figure 10. Analysis of gelatinolytic activity using gelatin-zymography. Visible clear bands conform to the $66 \mathrm{kDa}$ activated form of MMP-2.

genes, both coding for proteins needed in detoxification as well as HES1 are oppositionally regulated in Hep2 and HLaC79 cell lines $(\mathrm{AKR} 1 \mathrm{C} 1 \mathrm{HLaC79} \log \mathrm{FC}=-1.51 ; \mathrm{Hep} 2 \log \mathrm{FC}=3.03$; AKR1C3 HLaC79 $\operatorname{logFC}=-1.43$; Hep2 $\operatorname{logFC}=3.28$; HES1 $\mathrm{HLaC} 79 \log \mathrm{FC}=-2.04 ;$ Hep2 $\log \mathrm{FC}=1.75)$.

$q R T-P C R$. To test array results on specificity for Galium treatment a few interesting candidate genes were picked out and qRT-PCR with Galium-treated and untreated cells of the cell lines Hep2, Hep2-Tax, HLaC79, HLaC79-Tax and Fadu was performed. Expression induction/repression of TXNIP, MDM2 and RND3 differentially induced/repressed by Galium extract in Hep2 cells and JUN and MMP-10 in HLaC79 cells was tested. Results are summarized in Fig. 12.

Matrix metalloproteinase 10 (MMP-10) and c-Jun (JUN) were downregulated significantly in HLaC79 cells after Galium treatment. HLaC79 cells expressed vast amounts of c-jun at the stage of RNA isolation for the cDNA array. In the other cell lines, however, qRT-PCR revealed no clear tendency towards up or downregulation of JUN by Galium decoction. It is remarkable, however, that basic expression levels in all other cell lines are much lower than in HLaC79.

MMP-10 was significantly downregulated in HLaC79 cells after Galium treatment. There was no amplification of MMP-10 in Hep2 and Hep2-Tax cells. Expression was diminished in HLaC79 cell line. In Fadu and HLaC79-Tax cells, however, MMP-10 expression increased after Galium incubation (in Fadu significantly, in HLaC79-Tax cells not significantly, unpaired t-test).

Of the genes differentially affected in expression by Galium in Hep2 cells the tumour suppressor gene Thioredoxininteracting protein (TXNIP) was chosen. TXNIP was significantly upregulated by Galium aqueous extract in Fadu, Hep2 and Hep2-Tax cells. In HLaC79 and HLaC79-Tax cell lines, expressing low amounts (HLaC79) or no TXNIP (HLaC79-Tax) induction could not be achieved by Galium aqueous extract.

Mouse double minute 2 homolog (MDM2) was significantly downregulated in Hep2 cells $48 \mathrm{~h}$ after Galium decoction treatment. Negative gene regulation by Galium aqueous extract was confirmed to be significant in Fadu cells, in HLaC79 cells without significance. The chemoresistant cell lines showed upregulation of MDM2 (significant in HLaC79-Tax, not significant in Hep2-Tax).

The regulation of RND3/RhoE, which belongs to the Rho family of small GTP-binding proteins was also examined. RND3 was downregulated significantly in Hep2, Fadu and HLaC79 cells following Galium verum treatment. Similar 
Co

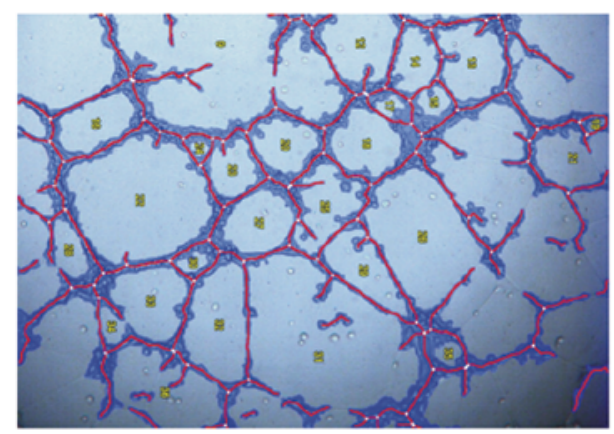

$\mathrm{Ga} 66.6 \mu \mathrm{l} / \mathrm{ml}$

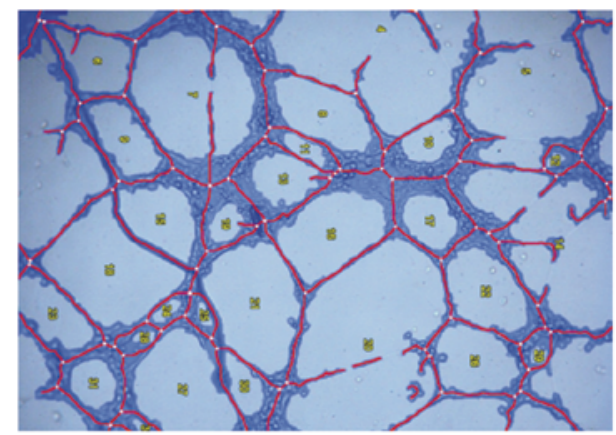

\section{Tube formation assay}
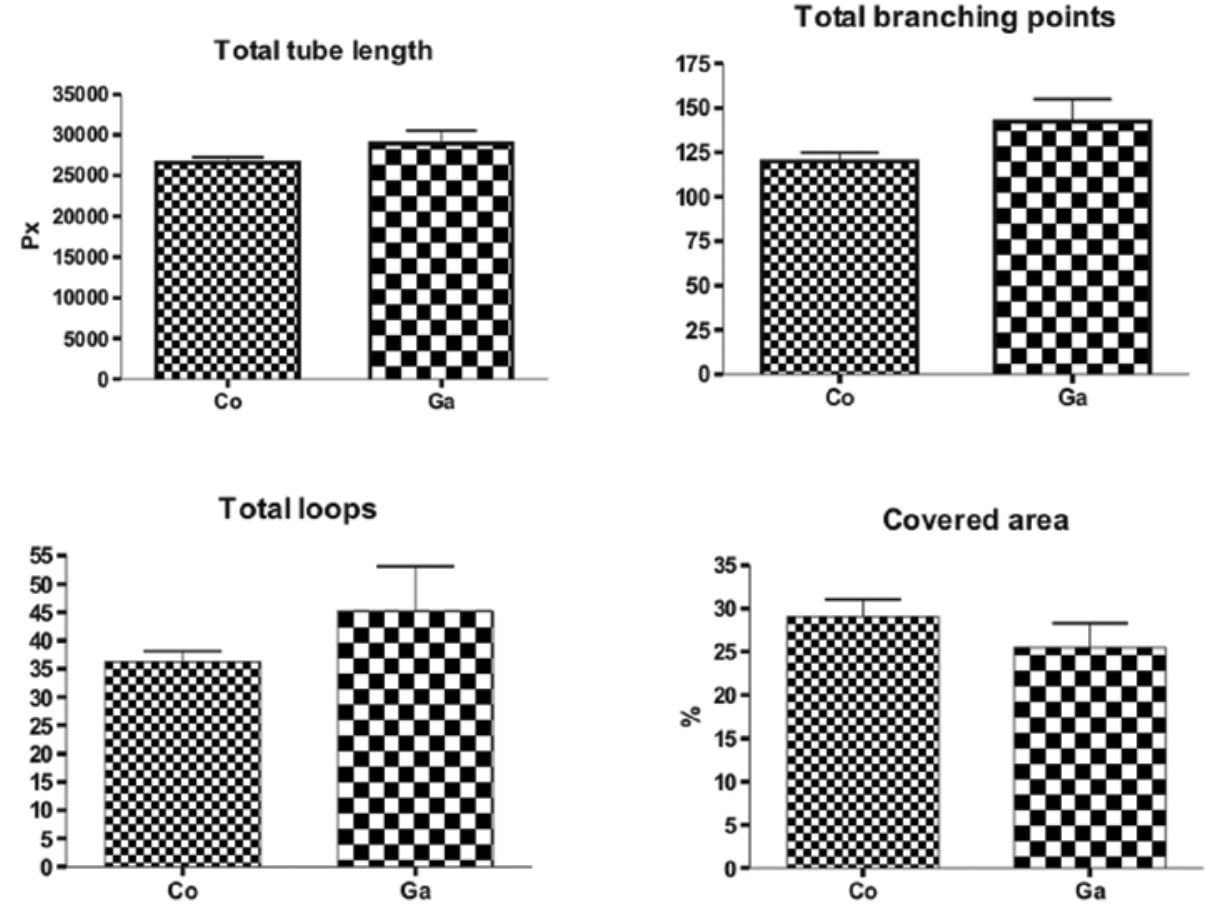

Figure 11. Measurement of angiogenesis with the tube formation assay. HUVEC tube formation was tested with or without Galium aqueous extract (66.6 $\mu 1 / \mathrm{ml})$. Total tube length (measured in pixels, px), number of branching points, number of total loops and percentage covered area (\%) were measured.

to MDM2, an inverse reaction in the chemoresistant clones (significantly upregulated in Hep2-Tax, not significant in HLaC79-Tax) was observed.

\section{Discussion}

In advanced laryngeal and hypopharyngeal cancer the chemotherapeutic agent paclitaxel is commonly used for chemotherapy in order to preserve laryngeal and/or pharyngeal structures. Chemotherapeutic failure, frequently observed in head and neck cancer, may be related either to inherited resistance against the drug or/and the acquired resistance during the therapy. One mechanism of drug resistance in cancer cells is the overexpression of multi-drug resistance proteins, such as P-glycoprotein (coded by the multi-drug resistance gene 1 , MDR-1, P-Gp), here clearly shown to be upregulated in paclitaxel-resistant clones of Hep2 and HLaC79 cell lines. Galium verum is a traditional medical plant commonly used for the exogenous cure of psoriasis, delayed wound healing or as a tea with diuretic effect for the cure of pyelitis or cystitis (3).

Some popular compendia for herbal medicine recommend Galium verum for therapy of mouth/neck cancer $(4,5)$. According to Jonathan Hartwells detailed survey (18) Galium verum was traditionally used in Europe and Northern America for treatment of cancerous ulcers or breast cancer. In the present study the effect of a simple decoction of Herba gallii lutei on chemo-sensitive and -resistant cell lines of laryngeal carcinoma was tested and significant growth inhibition in chemo-sensitive and -resistant cell lines, albeit somewhat extenuated in the paclitaxel-resitant clones was demonstrated. This is in agreement with Amirghofran et al (19), showing a cytotoxic effect of Galium mite methanolic extracts on K561 and Jurkat cells. Using sublethal doses of Galium verum decoction the influence on endothelial tube formation (angiogenesis) 
MMP10

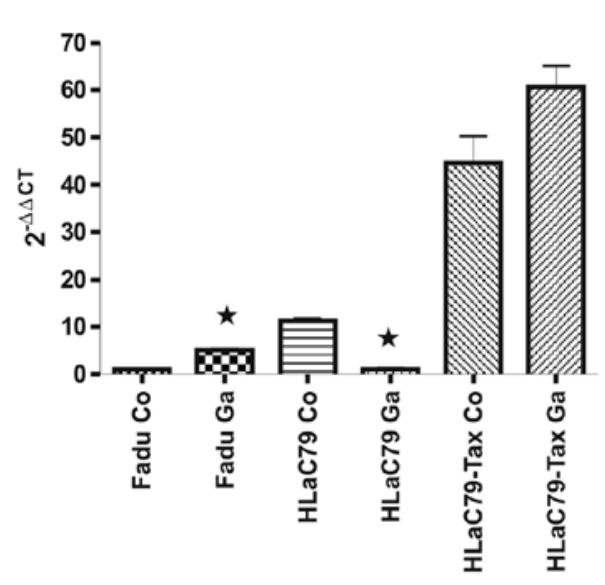

JUN

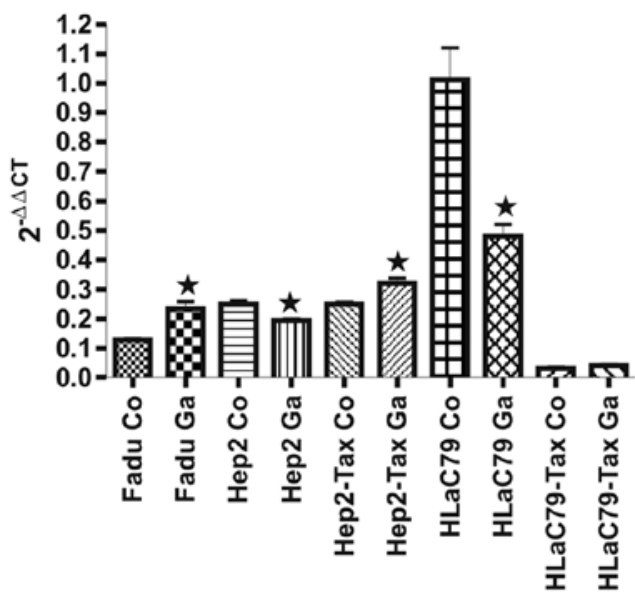

MDM-2

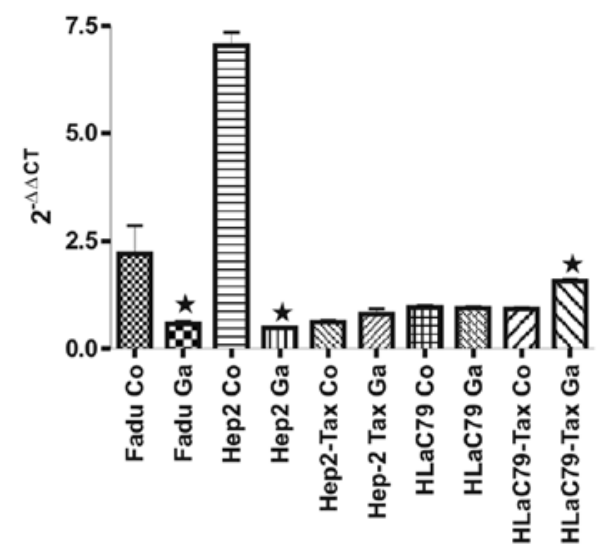

RND3
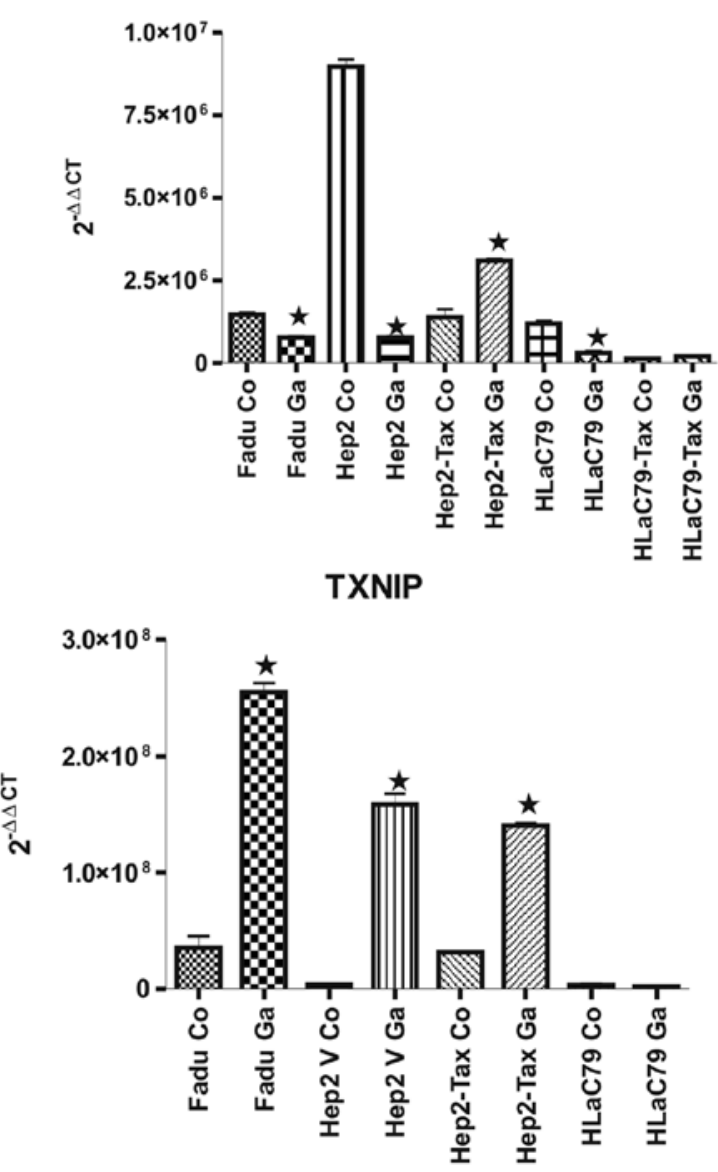

Figure 12. Gene expression of selected genes induced/repressed by Galium verum aqueous extract in Hep2 or HLaC79 cells, respectively. Significant differences are marked by an asterisk (unpaired t-test).

was examined, this study revealed no detectable effect. Even higher doses of Galium verum decoction did not suppress the development of a visible cordal network.

For the first time, a detailed motility/invasion analysis with tumour spheroids, invading diverse ECM substrates with or without low doses of Galium decoction was performed. Invasion was inhibited on all five substrates (gelatin, fibronectin, laminin, collagen I, and Matrigel) by Galium verum aqueous extract in chemosensitive as well as in chemoresistant cell lines. Comparing the percentage of reduction in cell migration, a more pronounced inhibition of invasion in the highly motile chemoresistant Hep2-Tax clone was observed. Thus, anti-invasive properties of Galium verum are remarkable.

As active compounds, in the Galium verum extract used, TLC identified among others chlorogenic acid, Luteolin-7$\mathrm{O}$-glucoside as well as rutoside. Comparing TLC patterns of methanolic and aqueous Galium extract, an enrichment of chlorogenic acid in the aqueous decoction was observed, while 
many other substances, such as apigenin, diminished without alcoholic solvent. Yagasaki et al (35) showed an obvious inhibition of invasion in rat teratoma cell lines caused by chlorogenic acid at doses, not growth inhibiting. This is in agreement with the present results. Jin et al (36) identified chlorogenic acid to be a strong suppressor of MMP-9 activity. In the current study, MMP-2 gelatinolytic activity was suppressed in HLaC79, HLaC79-Tax and Hep2 cells. This effect may be caused by chlorogenic acid, but also by other ingredients.

Luteolin7-O-glucoside has been shown to induce apoptosis in colon cancer cell lines and to effectively inhibit experimental colon carcinogenesis in vivo (37). The combination of several migration inhibitory substances may explain the strong inhibitory effect on migration of Galium verum aqueous extract.

In the actual study, TLC analysis was performed for identification of the used aqueous extract of Galium verum. Only the main flavonoids and phenolic acids were tested. Former detailed chromatographic analyses of Galium extracts (throughout nonaqueous extracts) identified many powerful ingredients such as iridoidglycosides (asperuloside, monotropeine, scandoside and daphylloside), flavonoids/flavonoid-glycosides (quercetin3-glucoside, quercetin-7-glucoside, diosmetin and palustrosid (reviewed in ref. 3), as well as anthraquinones (12) in Galium extracts. A detailed HPLC analysis would probably identify more ingredients, qualifying as candidates for the effects observed in our cell lines. The intention, however, was to evaluate the worth of an aqueous extract as a whole, historically used as an anticancer remedy.

Analysis of gene expression revealed no consistent patterns of changes in Hep2 and HLaC79 cells. Of 48,736 analysed genes, 367 were significantly differentially expressed in Hep 2 cells and 279 in HLaC79 cells following Galium treatment. There were only 11 genes affected significantly in both cell lines, three of them regulated in opposite directions (AKR1C3, AKR1C1 and HES1), although initial expression values did not differ greatly. Enzymes of the aldo/keto reductase superfamily catalyse the conversion of aldehydes and ketones to their corresponding alcohols with specific substrates for each family member. AKRC1 and AKRC3 are involved in the metabolism of progesterone or prostaglandines, respectively. It seems that regulation of these genes is also dependent on hormonal stage of the cell line. Generally it seems that gene activation/suppression caused by Galium verum extract is cell-type dependent, rather than the activation of a fixed cascade of genes caused by the ingredients of the extract. A clearer image might appear if expression arrays are performed earlier after induction to capture immediate early gene response. A further approach might be the testing of single ingredients of the extract, such as chlorogenic acid, to focus on common pathways activated by the substance. Nevertheless, some of the significantly Galium-regulated genes were picked out and tested in a variety of cell lines, treated with Galium aqueous extract vs. untreated controls.

Thioredoxin-interacting protein (TXNIP) showed a tendency to be upregulated in most cell lines upon Galium treatment, whereas HLaC79-Tax and HLaC79 cells expressing no or only low amounts of TXNIP. Induction could not be achieved in these cell lines by Galium treatment. TXNIP which is frequently repressed in human cancers can also inhibit metastasis (reviewed in ref. 38).

C-jun, coded by the JUN gene is an oncogenic transcription factor (reviewed in ref. 39). In breast cancer c-jun had been associated with proliferation and angiogenesis (40). In the study JUN was significantly downregulated in HLaC79 cells expressing vast amounts of c-jun at the stage of RNA isolation for the cDNA array. In the other cell lines there was no clear tendency towards up or downregulation of JUN by Galium decoction. Fadu and Hep2-Tax cells even reacted by increasing JUN expression. Therefore, it seems that the strong inhibitory effect of Galium on JUN expression is cell type specific, or responsible for 'normalization' of the punctual strongly upregulated JUN transcription.

Furthermore, the influence of Galium aqueous extract on the expression of MMP-10 was tested, which was significantly downregulated in HLaC79 cells due to Galium treatment. In Hep2 and Hep2-Tax cells, there was no amplification of MMP-10 transcript detectable either with or without Galium treatment. Expression was diminished in HLaC79 cells, in Fadu and HLaC79-Tax cells, however, MMP-10 expression increased after Galium incubation (in HLaC79-Tax cells not significantly), and therefore seems not to be a specific candidate for Galium caused gene regulation.

Mouse double minute 2 homolog (MDM2) is an E3 ubiquitin ligase, known as oncogene, overexpressed in many cancer types (reviewed in ref. 41). MDM2 was significantly downregulated in Hep2 cells, 48 h after Galium decoction treatment. Negative gene regulation by Galium aqueous extract was confirmed in Fadu cells as statistically significant, in HLaC79 cells without significance (unpaired t-test with $\mathrm{p}<0.05$ ). The chemoresistant cell lines showed upregulation of MDM2 (significant in HLaC79-Tax, not significant in Hep2-Tax). Qin et al (41) reviewed the role of natural products such as flavonoids and isoflavonoids in inhibiting MDM2 expression. Reduction of MDM2 expression was reached with genistein, apigenin and oroxylin A. These flavonoids/isoflavonoids were not reported yet to be ingredients of Galium extracts, but other flavonoids or other secondary plant products may also contribute to MDM2 downregulation. The lack of downregulation in the paclitaxel-resistant clones might be caused by P-Gp overexpression and the resulting detoxification. At least it seems likely, that the composition of the chemical cocktail active inside the cell differs between chemo-sensitive and -resistant cell lines.

RND3/RhoE belongs to the Rho family of small GTP-binding proteins. Most Rho family members cycle between a GTP-bound active and a GDP-bound inactive form. RND3/ RhoE is an atypical member of the Rho family, regulated rather by expression levels than by GTP/GDP cycling (reviewed in ref. 42). The role of RND3/RhoE in cancer and metastasis is still unclear; controversial results concerning the expression have been published. While RND3 has been shown to be downregulated in hepatocellular carcinoma (43) or prostate carcinoma (44) it has been reported to be upregulated in nonsmall cell lung cancer (45) or colon carcinoma (46). In vitro RND3 expression has been associated with melanoma cell migration and invasive outgrowth (47). In the present study, RND3 was downregulated significantly in Hep2, Fadu and 
HLaC79 cells following Galium verum treatment. Similar to MDM2, we observed an inverse reaction in the chemoresistant clones (significant upregulated in Hep2-Tax, not significant in HLaC79-Tax). It would, therefore, be interesting to test spheroid-based invasion on different ECM substrates of RND3 knocked out chemo-sensitive and -resistant cells.

Summarizing the results Galium verum aqueous extract revealed a growth inhibiting effect on chemo-sensitive and -resistant laryngeal carcinoma cell lines. In non-toxic concentrations Galium extract inhibited significantly, invasion of Hep2 and Hep2-Tax cells within collagen gels and on all ECM substrates tested, and was most pronounced in the aggressively invading chemoresistant Hep2-Tax cell line. Angiogenesis, however, was not affected by Galium decoction. Gene expression profiling did not reveal unique gene induction/repression patterns in HLaC79 and Hep2 cell lines, suggesting, that hormonal, metabolism and/or differentiation stage of HLaC79 and Hep2 cell lines are too divergent for focussing common pathway inductions. The obvious anti-metastatic effect of Galium decoction may justify a concomitant therapeutic use for oral or head and neck cancer.

\section{Acknowledgements}

We are grateful to Dr Carol Box and Professor Sue Eccles (The Institute of Cancer Research, London, UK) for constructive support and valuable tips concerning invasion experiments. We would like to thank Dr Ivo Pischel (PhytoLab GmbH \& Co. $\mathrm{KG}$ ) for supply of Herba gallii lutei, for providing hints and for critical discussion of scientific data. We further like to thank Dr Johannes Gottfried Mayer and Dr Heike Will (University of Wuerzburg, Forschergruppe Klostermedizin) for providing historical data and for stimulating discussion. We appreciate the critical reading of the manuscript by Clemens Otto.

\section{References}

1. Guntinas-Lichius O, Wendt T, Buentzel J, et al: Head and neck cancer in Germany: a site-specific analysis of survival of the Thuringian cancer registration database. J Cancer Res Clin Oncol 136: 55-63, 2010.

2. Pfreundner L, Hoppe F, Willner J, Preisler V, Bratengeier K, Hagen R, Helms J and Flentje M: Induction chemotherapy with paclitaxel and cisplatin and CT-based 3D radiotherapy in patients with advanced laryngeal and hypopharyngeal carcinomas - a possibility for organ preservation. Radiother Oncol 68: 163-170, 2003.

3. Hager ROM: Hagers Enzyklopaedie der Arzneistoffe und Drogen. Wiss. Verl.-Ges. Springer, Stuttgart (In German).

4. Treben M: Gesundheit aus der Apotheke Gottes. Ennsthaler Verlag, Steyr, 1980 (In German).

5. Willfort R: Gesundheit durch Heilkräuter. Trauner Verlag, 1982 (In German).

6. Neuthaler H: Das neue Kräuterbuch. Gesund durch Heilkräuter und moderne Naturheilkunde. Andreas Verlag Salzburg, 1978 (In German).

7. Böjthe-Horváth K, Hetényi F, Kocsis A, Szabo L, VargaBalázs M, Máthé I and Tétényi P: Iridoid glycosides from Galium verum. Phytochemistry 21: 2917-2919, 1980.

8. Zhao C, Shao J, Cao D, Zhang Y and Li X: Chemical constituents of Galium verum. Zhongguo Zhong Yao Za Zhi 34: 2761-2764 2009 (In Chinese).

9. Corrigan D, Timoney RF and Donnelly DMX: Iridoids and alkanes in twelve species of Galium and Asperula. Phytochemistry 17: 1131-1133, 1978.

10. Shafaghat A, Salimi F, Aslaniyan N and Shoaei Z: Flavonoids and an ester derivative isolated from Galium verum L. World Appl Sci J 11: 473-477, 2010.
11. Zhao CC, Shao JH, Li X, Kang XD, Zhang YW, Meng DL and $\mathrm{Li}$ N: Flavonoids from Galium verum $\mathrm{L}$. J Asian Nat Prod Res 10: 613-617, 2008.

12. Zhao CC, Shao JH, Li X, Xu J and Wang JH: A new anthraquinone from Galium verum L. Nat Prod Res 20: 981-984, 2006.

13. Borisov MI, Kovalev VN and Zaitsev VG: The chemical composition of Galium verum. Chem Nat Comp 7: 511, 1971.

14. Mavi A, Terzi Z, Ozgen U, Yildirim A and Coşkun M: Antioxidant properties of some medicinal plants: Prangos ferulacea (Apiaceae), Sedum sempervivoides (Crassulaceae), Malva neglecta (Malvaceae), Cruciata taurica (Rubiaceae), Rosa pimpinellifolia (Rosaceae), Galium verum subsp. verum (Rubiaceae), Urtica dioica (Urticaceae). Biol Pharm Bull 27 : 702-705, 2004.

15. Khaliq Jan A, Raza Shah M, Anis I and Khan Marwat I: In vitro antifungal and antibacterial activities of extracts of Galium tricornutum subsp. longipedunculatum. J Enzyme Inhib Med Chem 24: 192-196, 2009.

16. Morimoto M, Tanimoto K, Sakatani A and Komai K: Antifeedant activity of an anthraquinone aldehyde in Galium aparine L. against Spodoptera litura F. Phytochemistry 60: $163-166,2002$.

17. Tzakou O, Mylonas $\mathrm{P}$, Vagias $\mathrm{C}$ and Petrakis PV: Iridoid glucosides with insecticidal activity from Galium melanantherum. Z Naturforsch C 62: 597-602, 2007.

18. Hartwell JL: Plants used against cancer: a survey. Quarterman Publications, Lawrence, MA, 1982.

19. Amirghofran Z, Bahmani M, Azadmehr A and Javidnia K: Anticancer effects of various Iranian native medicinal plants on human tumor cell lines. Neoplasma 53: 428-433, 2006.

20. Zhao R, Chen Z, Jia G, Li J, Cai Y and Shao X: Protective effects of diosmetin extracted from Galium verum L. on the thymus of U14-bearing mice. Can J Physiol Pharmacol 89: 665-673, 2011.

21. Zenner HP, Lehner W and Herrmann IF: Establishment of carcinoma cell lines from larynx and submandibular gland. Arch Otorhinolaryngol 225: 269-277, 1979.

22. Baudin B, Bruneel A, Bosselut N and Vaubourdolle M: A protocol for isolation and culture of human umbilical vein endothelial cells. Nat Protoc 2: 481-485, 2007.

23. Wagner $\mathrm{H}$ and Bladt S: Plant drug analyses - a thin layer cromatography atlas. Springer Verlag Berlin, Heidelberg, New York, 1996.

24. Ghita G, Necula R, Trifan A, Gille E, Zamfirache MM and Stanescu U: Investigations regarding the phytochemical study of some samples of Galium verum $\mathrm{L}$ and Galium album mill. Scientific Annals of Alexandru Ioan Cuza University of Iasi, new series, Section IIa, Vegetal Biol 58: 45-50, 2012.

25. Lowry OH, Rosebrough NJ, Farr AL and Randall RJ: Protein measurement with the Folin phenol reagent. J Biol Chem 193: 265-275, 1951.

26. Kyhse-Andersen J: Electroblotting of multiple gels: a simple apparatus without tank for rapid transfer of proteins from polyacrylamide to nitrocellulose. J Biochem Biophys Methods 10: 203-209, 1984.

27. Vinci M, Gowan S, Boxall F, et al: Advances in establishment and analysis of three-dimensional tumor spheroid-based functional assays for target validation and drug evaluation. BMC Biol 10: 29, 2012 .

28. Vinci M, Box C, Zimmermann $M$ and Eccles SA: Tumor spheroid-based migration assays for evaluation of therapeutic agents. Methods Mol Biol 986: 253-266, 2013.

29. Heussen C and Dowdle EB: Electrophoretic analysis of plasminogen activators in polyacrylamide gels containing sodium dodecyl sulfate and copolymerized substrates. Anal Biochem 102: 196-202, 1980.

30. Irizarry RA, Hobbs B, Collin F, et al: Exploration, normalization, and summaries of high density oligonucleotide array probe level data. Biostatistics 4: 249-264, 2003.

31. Bolstad BM, Irizarry RA, Astrand M and Speed TP: A comparison of normalization methods for high density oligonucleotide array data based on variance and bias. Bioinformatics 19: 185-193, 2003.

32. Kendziorski CM, Newton MA, Lan H and Gould MN: On parametric empirical Bayes methods for comparing multiple groups using replicated gene expression profiles. Stat Med 22: 3899-3914, 2003.

33. Huang da W, Sherman BT and Lempicki RA: Bioinformatics enrichment tools: paths toward the comprehensive functional analysis of large gene lists. Nucleic Acids Res 37: 1-13, 2009. 
34. Livak KJ and Schmittgen TD: Analysis of relative gene expression data using real-time quantitative PCR and the 2(-Delta Delta C(T)) method. Methods 25: 402-408, 2001.

35. Yagasaki K, Miura Y, Okauchi R and Furuse T: Inhibitory effects of chlorogenic acid and its related compounds on the invasion of hepatoma cells in culture. Cytotechnology 33: 229-235, 2000.

36. Jin UH, Lee JY, Kang SK, et al: A phenolic compound, 5-caffeoylquinic acid (chlorogenic acid), is a new type and strong matrix metalloproteinase-9 inhibitor: isolation and identification from methanol extract of Euonymus alatus. Life Sci 77 2760-2769, 2005.

37. Baskar AA, Ignacimuthu S, Michael GP and Al Numair KS: Cancer chemopreventive potential of luteolin-7-O-glucoside isolated from Ophiorrhiza mungos Linn. Nutr Cancer 63: 130-138, 2011.

38. Zhou J, Yu Q and Chng WJ: TXNIP (VDUP-1, TBP-2): a major redox regulator commonly suppressed in cancer by epigenetic mechanisms. Int J Biochem Cell Biol 43: 1668-1673, 2011.

39. Vogt PK: Fortuitous convergences: the beginnings of JUN. Nat Rev Cancer 2: 465-469, 2002.

40. Vleugel MM, Greijer AE, Bos R, van der Wall E and van Diest PJ: c-Jun activation is associated with proliferation and angiogenesis in invasive breast cancer. Hum Pathol 37: 668-674, 2006.
41. Qin JJ, Nag S, Voruganti S, Wang W and Zhang R: Natural product MDM2 inhibitors: anticancer activity and mechanisms of action. Curr Med Chem 19: 5705-5725, 2012.

42. Chardin P: Function and regulation of Rnd proteins. Nat Rev Mol Cell Biol 7: 54-62, 2006.

43. Grise F, Sena S, Bidaud-Meynard A, et al: Rnd3/RhoE is downregulated in hepatocellular carcinoma and controls cellular invasion. Hepatology 55: 1766-1775, 2012.

44. Bektic J, Pfeil K, Berger AP, et al: Small G-protein RhoE is underexpressed in prostate cancer and induces cell cycle arrest and apoptosis. Prostate 64: 332-340, 2005.

45. Zhang C, Zhou F, Li N, et al: Overexpression of RhoE has a prognostic value in non-small cell lung cancer. Ann Surg Oncol 14: 2628-2635, 2007.

46. Zhou J, Yang J, Li K, et al: RhoE is associated with relapse and prognosis of patients with colorectal cancer. Ann Surg Oncol 20: 175-182, 2013.

47. Klein RM and Aplin AE: Rnd3 regulation of the actin cytoskeleton promotes melanoma migration and invasive outgrowth in three dimensions. Cancer Res 69: 2224-2233, 2009. 